\title{
Mirrabella, a new name for the genus Mirabella De Bruijn et al., 1987 (Mammalia), preoccupied by Mirabella Emeljanov, 1982 (Insecta)
}

\author{
Hans de Bruijn ${ }^{1}$, Lars W. van den Hoek Ostende ${ }^{2}$, Stephen K. Donovan ${ }^{2}$ \\ ${ }^{1}$ Department of Geosciences, University of Utrecht, PO Box 80021, 3508 TA Utrecht, hdbruijn@geo.uu.nl; \\ ${ }^{2}$ Nationaal Natuurhistorisch Museum, PO Box 9517, NL-2300 RA Leiden, The Netherlands, hoek@naturalis.nl, \\ donovan@naturalis.nl
}

De Bruijn et al. (1987) described a new genus of cricetid-like muroid rodent, Mirabella, from the eastern Mediterranean. The type species is M. tuberosa from the Early Miocene locality of Aliveri (Island of Evia, Greece). The name had already appeared in Benda and De Bruijn (1982), but only as a nomen nudum. Apart from the type species, De Bruijn et al. (1987) also defined $M$. intermedia from the Anatolian locality of Harami I. However, this species was transferred subsequently to Deperetomys (De Bruijn et al., 1993). Instead, another Mirabella, M. anatolica, was described, also from Harami I, as well as M. crenulata from the somewhat younger locality of Keseköy (De Bruijn and Saraç, 1992). The presence of the genus in two central European localities was also noted therein. The original classification in the Eucricetodontinae, partly based on the species intermedia, was changed into Paracricetodontinae. Unfortunately, Kalthoff $(2000,2006)$ did not analyse the microstructure of the lower incisors of Mirabella, so its allocation remains uncertain for the time being.

However, the name Mirabella had already been used for a homopteran from Mongolia (Emeljanov, 1982). The type species of this genus is the extant $M i$ rabella albifrons (Fieber, 1866) from eastern and northern mainland Europe (Fauna Europaea, 2007).

For completeness, it is also relevant to mention that Barskova (1988a; English translation Barskova, 1988b) described a small suite of fossil molluscs from the Kolyma Uplift in eastern Asia. One new genus was erected, Mirabella, assigned to 'Класс Gastropoda? inc[ertae] sed[is]' (Barskova, 1988a, p. 104). The shelly Mirabella was based on a few specimens of a single species, Mirabella ridicula Barskova, 1988a, from the Atdabanian (Lower Cambrian) exposed in the 'lower reaches of the Bolshaya Stolbovaya River' (Barskova, 1988b, p. 102). However, Mirabella Barskova, 1988a, is a junior synonym of Micrina Laurie, 1986 (P. Parkhaev, written comm. to L.W.v.d.H.O., March 2007), although the species ridicula was not listed as an 'other species' in the recent discussion by Li and Xiao (2004, p. 909).

The authors of these taxa, in erecting a generic name that linked a Cambrian snail, a Miocene hamster and an extant plant-sucking bug, apparently considered the morphology of their respective type species to be aberrant, which lead to the use of the same name (Mirabella $=$ miraculous, L.). The homonomy of the hamster and the snail was discovered while entering information into the Paleobiological Database; one of our reviewers drew our attention to that of the homopteran (S. Bengtson, written comm., March 2007). The description of both the homopteran and the hamster Mirabella comply by the requirements of the International Code of Zoological Nomenclature. Thus, Mirabella De Bruijn et al., 1987, is a junior homonym of Mirabella Emeljanov, 1982. We therefore propose the name Mirrabella nom. nov. for Mirabella De Bruijn et al., 1987, not Emeljanov, 1982. The new name attempts to preserve the sense of the original by a minor modification of the spelling. The type species of Mirrabella is Mirabella tuberosa De Bruijn et al., 1987, by original designation.

\section{Acknowledgements}

Pavel Parkhaev (Paleontological Institute, Russian Academy of Sciences) is thanked for his comments on the affinities of $\mathrm{Mi}$ rabella Barskova, 1988a. The informed comments of Stefan Bengtson (Swedish Museum of Natural History, Stockholm) and a second, anonymous referee are gratefully acknowledged. This is publication number 67 of the Paleobiology Database. 


\section{References}

Barskova MI. 1988a. Novyye mollyuski iz nizhnekembriyskikh otlozheniy prikolymskogo podnyatiya. Paleontologiceskij Zhurnal 1988: 101-105. [In Russian.]

Barskova MI. 1988b. New Lower Cambrian mollusks from the Kolyma Uplift. Paleontological Journal 22: 98-104. [English translation of Barskova, 1988a.]

Benda L, Bruijn H De 1982. Biostratigraphic correlations in the Eastern Mediterranean Neogene. Part 7. Calibration of sporomorph and rodent-associations in the Aliveri-Kymi basin (Island of Euboea (Greece). Newsletters on Stratigraphy 11: 128-135.

Bruijn H De, Fahlbusch V, Saraç G, Ünay E. 1993. Early Miocene rodent faunas from the eastern Mediterranean area Part III. The genera Deperetomys and Cricetodon with a discussion of the evolutionary history of the Cricetodontini. Proceedings van de Koninklijke Nederlandse Akademie van Wetenschappen 96: 151-216.

Bruijn H De, Saraç G. 1992. Early Miocene rodent faunas from the eastern Mediterrenean area Part II. Mirabella (Paracricetodontinea, Muroidea). Proceedings van de Koninklijke Nederlandse Akademie van Wetenschappen 95: 25-40.

Bruijn H De, Ünay E, Saraç G, Klein Hofmeijer G. 1987. An unusual new eucricetodontine from the Lower Miocene of the Eastern Mediterranean. Proceedings van de Koninklijke Nederlandse Akademie van Wetenschappen, Series B 90: 119-132.

Emeljanov AF. 1982. Fulgoroidea (Homoptera) collected in the Mongolian People's Republic by the entomofaunistical group of the Soviet-Mongolian complex biological expedition in 1970-1975. Nasekomye Mongolii 8: 69-122. [In Russian.]

Fauna Europaea. 2007. Distribution. Version 1.3 (updated 19 April 2007). www.faunaeur.org/distribution_table. [Visited 6 July 2007.]

Fieber FX. 1866. Grundzüge der generischen Theilung del Delphacini. Verhandlungen der Kaiserlich Königlichen Zoologisch-Botanischen Gesellschaft in Wien 16: 517-534. [Not seen.]

Kalthoff, DC. 2000. Die Schmelzmicrostruktur in den Incisiven der hamsterartigen Nagetiere und anderer Myomorpha (Rodentia, Mammalia). Palaeontographica A 259: 1-193.

Kalthoff, DC. 2006. Incisor enamel structure and its implications to higher-level systematics of Eurasian Oligocene and Early Miocene hamsters (Rodentia). Palaeontographica $A$ 277: $67-80$

Laurie JR. 1986. Phosphatic fauna of the Early Cambrian Todd River Dolomite, Amadeus Basin, central Australia. Alcheringa 10: 431-454.

Li G, Xiao S. 2004. Tannuolina and Micrina (Tannuolinidae) from the Lower Cambrian of eastern Yunnan, South China, and their scleritome reconstruction. Journal of Paleontology 78: 900-913.

Received: 23 February 2007

Accepted: 1 October 2007 